\title{
Trigger factors in brick and click shopping
}

\author{
Mage Marmol ${ }^{1}$ (D), Vicenc Fernandez ${ }^{2}$ (D) \\ ${ }^{1}$ Euncet Business School (Universitat Politècnica de Catalunya $\bullet$ BarcelonaTech) (Spain) \\ ${ }^{2}$ Universitat Politècnica de Catalunya $\bullet$ BarcelonaTech (Spain) \\ mage.marmol@euncet.cat,vicenc.fernandez@upc.edu
}

Received September, 2018

Accepted April, 2019

\section{Abstract}

Purpose: The goal of this research is to describe the customer's purchase path in different shopping channels and to identify which are the trigger factors that motivate the choice of every shopping channel. The description of the factors that motivate this seamless experience across all channels will provide brands with knowledge about how to improve their strategic approach to engagement, belonging and retention of customers.

Design/methodology: This paper builds propositions about the trigger factors for shopping channel choice based on thirty reports from the main consultancy companies made during the last five years and coded regarding the main topics highlighted in the literature.

Findings: The findings of this study indicate that there are common trigger factors for every shopping channel and for every stage of the purchase path.

Research limitations/implications: The data are from different countries, segments and products although they show common patterns.

Originality/value: To date, little research in a complete vision of the shopping paths has been done. The definition of the different paths and the trigger factors associated to each one is unique and will help further research in this area.

Keywords: Omnichannel, multichannel, Purchase process, Customer experience, Purchase intention, Webrooming, showrooming, m-commerce, Bricks and clicks, Brick-and-mortar

Jel Codes: M3

\section{To cite this article:}

Marmol, M., \& Fernandez, V. (2019). Trigger factors in brick and click shopping. Intangible Capital, 15(1), 57-71. https://doi.org/10.3926/ic.1364

\section{Introduction}

Traditionally, customers made their purchases in brick-and-mortar stores with the help of salespeople to find what they wanted or needed and within a certain atmosphere. With the growth of technology and on-the-go 
devices, different shopping channels have appeared and have attracted the attention of customers. E-commerce gave customers the possibility to browse through different stores in an online environment and get information, opinions and a vast available stock. Although some experts predicted that online shops would kill the physical ones, the truth is that they coexist and have transformed the way customers shop nowadays (Galino \& Moreno 2014). Customers entered in a multichannel environment using different channels to shop (Mosquera, Olarte Pascual \& Juaneda Ayensa, 2017). Companies set then an omnichannel strategy so as to blur the borders among the different channels and offer the customer a seamless experience (Heitz-Spahn, 2013). Customers switch between channels, between retailers and between devices in a very natural way for different reasons and valuing different factors: brand perception, atmosphere, price, availability of stock, convenience or personalisation (Agnihotri 2015; Cap Gemini, 2017; Kibo, 2017; UPS, 2015; Willmott, 2014; Zimmerman, 2012). Knowing how customers move from one channel to another and how they combine them in a seamless experience is key for retailers so as to increase sales, retain them and enhance loyalty (Sands et al., 2016). The blending of bricks (the physical store) with clicks (the online environment) is boosting a whole new way of shopping. The seamless experience offered by brands across different shopping channels is key because a connected shopper spends 30\% more than an unconnected shopper (PSFK Labs; Cisco 2016).

This research was developed in three stages. First, we revised the existing literature to identify the purchase process theories and define the basic factors that affect each one. Due to the fact that this paper is intended to be a scoping review of the omnichannel environment, we have gathered not only papers from scientific and academic practitioners but also reports made by the most important consultancy companies in the field. The results obtained by these companies have helped us to have a clear and updated idea of the factors that motivate shopping in the different proposed channels.

After that, we defined the different omnichannel purchase processes based on the EKB Model (Kollat, Engel \& Blackwell, 1970) so as to determine if the purchase process in an omnichannel environment is somehow different from a process in a physical retail environment. Lastly, we made a comparison of the different channels and the purchase process so as to have a clear view of the trigger factors that affect every channel and every stage of the process. We have classified the phases of the classical consumer behaviour model (need recognition, information search, alternative evaluation, purchase and postpurchase) (Kollat et al., 1970) under an omnichannel approach in all possible combinations, i.e. shopping in the store, webrooming, showrooming, BOPS (Buy Online Pick up In Store), online shopping and mobile shopping. We consider the omnichannel shopping process as an integrated sales experience that melds the advantages of physical stores with the information-rich experience of online shopping (Rigby, 2011). More precisely, omniretailing is considered by Levy and Weitz (2013, pp. 67) as a coordinated multichannel offering that provides a seamless experience when using all the retailer's shopping channels.

Understanding customers' decision-making process to predict their future purchase intentions and behaviour has been the goal of many psychology, marketing and consumer-behaviour theories (Ryu \& Han, 2011). In order to maximize customers' purchase intentions, managers need to know the success factors influencing purchase intent and their relative importance (Frank, Enkawa \& Schvaneveldt, 2014). The description of the factors that motivate this seamless experience across all channels will provide brands with knowledge about how to improve their strategic approach to engagement, belonging and retention of customers.

\section{Literature Review}

\subsection{Multichannel and omnichannel shopping}

Customers shop around to get the best deal (Rajamma, Paswan \& Ganesh, 2007) but nowadays they are changing where, how and even why they shop (Nelson \& Leon 2012). Depending on whether the purchases are made in physical stores or online, they follow a very different process (Brynjolfsson, Hu \& Rahman, 2013). Traditionally, shopping took place only in physical stores and in a limited geographical region or city. They were the only channel that customers had to buy and therefore transactions where based on face-to-face personal relationships (Kim, Ferrin \& Rao, 2008). With the rise of internet another way of shopping was possible and customers 
started to shop online from their desktops (Sands et al., 2016). With the explosion of mobile technologies and social media, multichannel shopping has become a journey in which customers choose the route they take and which needs to be mapped to be understood (Wolny \& Charoensuksai, 2014). As a result, new shopping ways have emerged, for example webrooming, where consumers research products online before visiting a brick-andmortar store for final evaluation and purchase (Edwards, 2014) and the opposite, known as showrooming, where consumers visit retailers' stores to "touch and feel" a product, but they consummate their eventual purchase online (Fulgoni, 2014).

Multichannel shopping involves the use of basically online and offline channels one at a time. It implies a division between both environments (Juaneda-Ayensa, Mosquera \& Sierra, 2016). The increasing use of customer supportive technologies and applications within the physical retail store in the context of the multichannel retailing era enhanced shopping experience and store atmosphere (Lazaris et al., 2015). But multichannel fails in the integration of different shopping channels and appears unconnected and offers multiple shopping channels but focused on the process itself and not on the customer (Burke, 2002). Multichannel means that the customer has different shopping channels from which to choose the purchase but companies use also different strategies depending on one or another channel (Lazaris \& Vrechopoulos, 2013). For example, if a customer receives a coupon in an online channel, he may not exchange it on a physical store. With the increase of new technologies and their availability to the customer, a new way of shopping has appeared. With the rise of technology and on-the-go devices customers look for a seamless experience among channels and companies are focusing their strategies to coordinate them in a way that if offers the possibility to interact in all channels for a single purchase offering a shopping process without boundaries between the different channels.

Omnis is a Latin word meaning "all" or "universal," so omnichannel means "all channels together" (Lazaris \& Vrechopoulos, 2013). Because the channels are managed together, the perceived interaction is not with the channel, but rather with the brand (Piotrowicz \& Cuthbertson, 2014). Multichannel emphasizes the individual channel while omnichannel gives importance to customers' experience. Therefore, the difference between multichannel and omnichannel strategies relies on the approach and the management strategy used in every channel. In multichannel shopping all channels are available to the consumer but they are not integrated. Omnichannel shopping offers an integrated strategy and therefore the sense of connection and relationship with the brand no matter the channel the customer uses (Verhoef, Kannan \& Inman, 2015).

An omnichannel strategy understands the purchase as a process in which different channels participate. It is important to understand what drives customers to every channel so that companies can offer them a satisfactory purchase experience. No matter how the shoppers swap across channels and devices, the use of various channels and touchpoints are able to be consistent, concurrent and compatible (Melero, Sese \& Verhoef, 2016).

\subsection{Purchase process}

Several researchers (e.g. Howard \& Shethe, 1969; Ajzen, 2011; Kollat et al., 1970; Schiffman \& Wisenblit, 1995) have written about the purchase process. The EKB Model (Kollat et al., 1970) is one of the most spread theories and has been the base to subsequent transformations and new ideas. According to this theory, in a purchase process, a customer identifies a need, looks for information, evaluates alternatives, makes a decision and evaluates the purchase (Kollat et al., 1970).

Nowadays, the search for information and evaluation of alternatives can be done online or offline. In both cases, external sources like marketing efforts made by the brands, peers and family opinions and word-of-mouth can be determinant of a decision made by a customer (Khan et al., 2015). Online channel loyalty has been observed to be more toward products that belong to a "search category" rather than to an "experience category" (Kim \& Forsythe, 2007). In the same way, purchases can be made at brick-and-mortar stores or online and this fact makes it difficult to control the path that the customer makes towards a product or a service. A customer can start looking for information at a physical brick-and-mortar store and end the purchase there, which would be what traditional customers have always done. With the growth of technology, a new shopping scenario appeared, the online world gave the possibility to start and end the process there, or to start the process physically and end 
virtually, or vice versa. Moreover, the increasing use of mobile devices, opens another new way of shopping (Gao \& Yang, 2016). Looking at where the customer starts the search for information and where the purchase takes place, we enumerate the following classification of the path that the customer takes to complete a purchase:

- Traditional shopping path: start at brick-and-mortar stores and purchase at brick-and-mortar stores.

- Desktop path: start online, from a desktop or tablet at home and end the purchase at the same place.

- Showrooming path: start the purchase process at a brick-and-mortar store, where the customer gathers information and end online from a desktop or a tablet at the same brand or at a competing retailer (Gensler, Neslin \& Verhoef, 2017).

- Reverse showrooming path: so as to prevent the customer from switching brands, a new purchase path has appeared, the so called reverse showrooming, wherein retailers encourage bricks-and-mortar consumers to search their products online through kiosks or mobile apps, thereby increasing the likelihood of keeping the sale (Parise, Guinan \& Kafka, 2016).

- Webrooming path: the customer researches products online at home before visiting a brick-and-mortar store for final evaluation and purchase (Edwards, 2014).

- BOPS path: The customer buys online and picks up in physical store (Bell, Gallino \& Moreno, 2014).

- Mobile only path: the customer starts on a mobile device and ends his purchase on the same device (Beck \& Rygl, 2015).

All these shopping paths involve the use of one channel at a time and the physical transfer of the customer from one place to another to use those channels. As mentioned, in showrooming for example, the customer searches for information at the brick-and-mortar store and then goes to another place to buy online (Verhoef et al., 2015). Nevertheless, there is a possibility to use a mobile device at the same physical place to complete the purchase on site after looking for information (Gao \& Su, 2016). This is what we call "instant showrooming". Another situation is that of the customer who looks for information through a mobile device while in the store and completes the purchase at the store. We name this situation as "instant webrooming". Therefore, the abovementioned list, should be completed with two other paths:

- Instant showrooming path: the purchase process starts at a brick-and-mortar store and the purchase is made online but from a mobile device in the same store.

- Instant webrooming path: the customer looks for information online from his mobile device while in the store and buys at the same brick-and-mortar store.

There are two ways to group these different shopping paths. From the retailer's perspective, there are three different strategies: (1) single channel strategy by which the brand or retailer has only one shopping channel where to offer their products or services, either physical or on the web, (2) multichannel strategy which refers to the integration of various channels, not connected, in the consumer decision-making process (Wolny \& Charoensuksai, 2014) and omnichannel strategy, a holistic shopping experience through the integration of online and offline channels offering the customer a seamless experience (Mosquera et al., 2017). From the customer's perspective, the above explained paths can also be single channel (traditional brick-and-mortar physical stores, online shopping and mobile only), multichannel (showrooming and webrooming) and omnichannel (instant showrooming, instant webrooming, reverse showrooming and BOPS). The classification shown in Table 1takes into account the starting point, where the customer searches for information and the end point where the actual purchase is made. 


\begin{tabular}{|l|l|l|l|l|}
\cline { 2 - 4 } \multicolumn{1}{c|}{} & Path & Information search & Purchase \\
\hline \multirow{4}{*}{ Single channel } & Brick-and-mortar only & Brick-and-mortar & Brick-and-mortar \\
\cline { 2 - 4 } & Desktop only & Desktop & Desktop \\
\cline { 2 - 4 } & Mobile only & Mobile device & Mobile device \\
\hline \multirow{3}{*}{ Omnichannel } & Showrooming & Brick-and-mortar & Desktop (home) \\
\cline { 2 - 4 } & Webrooming & Desktop (home) & Brick-and-mortar \\
\cline { 2 - 4 } & Instant showrooming & Brick-and-mortar & showrooming \\
\cline { 2 - 4 } & Instant webrooming & Mobile device & Brick-and-mortar \\
\cline { 2 - 4 } & Reverse showrooming & Brick-and-mortar & Retailer's desktop \\
\cline { 2 - 4 } & BOPS & Desktop & $\begin{array}{l}\text { Desktop (pick up } \\
\text { brick-and-mortar) }\end{array}$ \\
\hline
\end{tabular}

Table 1. Classification of purchase paths

\subsection{Trigger factors for channel choice}

As we can see in Table 1, customers move around different channels starting at one channel and ending at the same or at another one. To know the reasons why customers choose these different paths to purchase is key and that is why we made research so as to determine what moves customers towards one or another of the mentioned paths. There are several trigger factors that push the customer toward the decision of shopping through one certain channel only (traditional brick-and-mortar shops or online stores) or through a multichannel experience. The most highlighted trigger factors are stock availability (Lazaris et al., 2015; Willmott, 2014; Beck \& Rygl, 2015; Gensler et al., 2017), personalisation (Burke, 2002; Nelson \& Leon, 2012; Karimi, Papamichail \& Holland, 2015; Rajamma et al., 2007), atmosphere (Andajani, 2015; Lazaris et al., 2015; Piotrowicz \& Cuthbertson, 2014; Ryu \& Han, 2011), price (Zeithaml, Berry \& Parasuraman, 1996; Pawar \& Sarmah, 2015; Hagberg, Sundstrom \& Egels-Zandén, 2016; Picot-Coupey, Huré \& Piveteau, 2016) and convenience (Gensler et al., 2017; Lemon \& Verhoef, 2016; Rigby et al., 2014).

The fundamental reason for shopping is to buy the product or the service, and this is guided by factors such as availability, quality and variety of merchandise (Rajamma et al., 2007). Research (Nelson \& Leon, 2012) has shown that one of the reasons for preferring online purchases is the variety of offer that cannot be found in physical stores. Store traffic and assortment may also influence the online and offline retailers' pricing strategies (Li, Lu \& Talebian, 2014). Customers do not make a second attempt if their first choice is out of stock (Li et al., 2014).

Another trigger factor is personalisation. Applying this point to the omnichannel model, if the product can be delivered quickly at a relatively low cost, the online channel is preferred whereas if the delivery cost is high and customers are impatient, the traditional channel is better ( $\mathrm{Li}$ et al., 2014). The increasing use of customer supportive technologies and applications within the physical retail store in the context of the omnichannel retailing era has enhanced shopping experience and store atmosphere (Lazaris et al., 2015). Feeling the right personal experience at a certain retail store can be a very important evaluative factor and lead the customer to repeat a purchase to feel the experience again. In the same way, a web atmospheric cue is comparable to a brickand-mortar atmospheric cue and can be defined as any web interface component that stimulates one's senses (Dailey, 2004). For example, 35\% of UK shoppers would be interested in attending a lifestyle lessor or club at their favourite store (Westfield 2015). This means that face-to-face relationships and personalisation are still important during the purchase process.

Nowadays, the increasing availability of comparative price information online make customers more pricesensitive (Degeratu, Rangaswamy \& Wu, 2000). Price seems to be one of the most important criteria to evaluate a purchase but it can be less taken into account if the other factors we have mentioned (stock availability, personalisation and convenience) are important for the customer (Gensler et al., 2017). Even if the online population becomes comparable to the general population, the combined effects of price and promotion seem to be stronger in brick-and-mortar stores than in online stores (Degeratu et al., 2000). Price comparison-oriented consumers move across channels to maximize their chances of finding the best deal (Heitz-Spahn, 2013). In 
showrooming specially, shoppers search for information in the store and simultaneously search on their mobile device to get more information about offers and may find more attractive prices (Rapp et al., 2015).

The literature, e.g. (Evanschitzky et al., 2004) identifies the convenience dimension as a key motivator for selecting a retail type. Convenience means that the customer seeks to purchase a product with a minimum investment of time, physical effort and mental effort (Schröder \& Zaharia, 2008). Multichannel retailing can be a strategy to attract and retain customers that value convenience and flexibility (Sands et al., 2016). Mobile technology is bringing internet to consumers 24 hours a day and convenience for them is an important factor to choose this channel (Brynjolfsson et al., 2013).

\section{Methodology}

With the purpose of conducting an in-depth analysis of what were the important factors for consumers during their purchase process in different channels, we designed an explorative approach through primarily qualitative data and therefore gathered over 30 reports from some of the most important consulting firms and a number of academic papers. The analysis of all the material was done in three phases. First, we gathered reports and academic papers. The search was made using the keywords "omnichannel" and "purchase process" and we chose only those reports produced during the past three years and signed by important consultancy companies in the marketing sector. The search in google resulted in 30 reports. The search in Web of Science, Scopus and Mendeley resulted in many academic papers that were the base of our next steps. All those reports older than 2014 and not mentioning any of our keywords were discarded.

Secondly, we read and analysed the documents to find references about our proposed trigger factors (product range or variety of stock, personalisation, price and convenience) and we coded all the reports with numbers from 1 to 30. We listed the main conclusions and results from every report. Based on our initial list of trigger factors, we extracted them from the reports and we made a list in which we noted the percentages of customers that considered a certain factor as a trigger for his choice of shopping channel. We took percentages over 55\% into account to consider them as a trend for our research.

Thirdly we constructed a table to summarize the results of our findings. On the vertical axis, we placed all the phases of the purchase process (need recognition, information search, alternative evaluation, purchase and post purchase) and on the horizontal axis we placed the omnichannel purchase paths (traditional shopping, webrooming, instant webrooming, showrooming, instant showrooming, Buy Online Pick up In Store, online only, mobile only). We read all the reports again and filled in the corresponding space in the table with conclusions extracted and with the code of the report. For example, if we were reading a report by Criteo (code number 9) concluding that $63 \%$ of the customers find the ability to check inventory on a retailer's app prior to the visit to the store, then we wrote this fact in the corresponding space (information search, webrooming).

Although the reports are diverse and from different countries, results show common trends that affect consumers and shopping in general.

\section{Results and discussion}

Results suggest that there are common trigger factors for every shopping channel and for every stage of the purchase path.

\subsection{Traditional shopping}

In the traditional way of shopping, the customer goes to a brick-and-mortar store so as to get information from sales associates mainly (PWC, 2017; UPS, 2016; Ivend, 2017). Customers expect sales associates to have a deep knowledge of product specifications and range. $89 \%$ of Millennials, that is, young consumers, born between approximately 1985 and 1999 (Kotler \& Keller, 2009) want personalization (Kibo, 2017) when shopping at a brick-and-mortar store. Another reason to shop in store is the atmosphere and the sense of touch and feel that cannot be found in other channels (Willmott, 2014). The way to reach customer satisfaction and engagement would be offering unique products and immediate availability (UPS, 2016). Even though it is not possible to 
discern if behavioural loyalty derives from a solid affective link or simply stems from greater convenience or accessibility, retailers aim to foster attitudinal and affective links with customers to the extent that it leads to desirable behaviours that contribute to their profit in the long run (Martos-Partal \& González-Benito, 2013). Another reason why customers prefer to buy at a brick-and-mortar store is the fact that they can take the products with them immediately (Cap Gemini, 2017). When consumers face time pressures, they benefit more from quicker service, fast access, quick payment and so forth. Their switching costs also are higher, which should make them more store loyal (Martos-Partal \& González-Benito, 2013). Offering time savings solutions to customers in store should be one of the main objectives for retailers if they want to keep customers and attract new ones. The top reasons to shop at small retailers are because of their unique products $(50 \%)$, for the community support (34\%), and because of sales associates help (23\%) (UPS, 2016). Nevertheless, the need to touch and feel is, by far, the most repeated reason among consumers $(70 \%)$. These results match with academic research and demonstrate that the one aspect that can provide advantages to traditional retailers of good repute is their outstanding capability to blend their unique resources such as reputation and physical presence with threshold resources like technology and product variety (Agnihotri, 2015). Almost half of shoppers say that engaging with them in innovative a creative ways to provide a multisensory experience influences their overall feeling of loyalty toward a brand (Accenture, 2017) and therefore, their purchase intention. Retailers should explore how to best use technology to move consumers through each of the stages in the purchase process (Burke, 2002).

\subsection{Desktop only}

As regards purchases that start and end on a desktop, one of the conclusions is that one of the most valued factors when shopping from a desktop is the ability to compare products and shops (Nelson \& Leon, 2012). The ability to get discounts or compare prices is also important for half or more of shoppers. Price is also a determinant factor for shopping online only as well as convenience (time saving and delivery) (IAB, 2016). The main reasons to buy online stated by consumers are convenience, time saving and money saving (IAB, 2016). Contrasting with in-store shoppers, $40 \%$ of desktop consumers prefer self-service to human contact for their future contact with companies (HP, 2014). Another important reason is stock availability and delivery. One of the most important conclusions issued from the reports is that $60 \%$ of consumers who start in web end in web (Ingenico, 2017). These conclusions are widely supported by academic literature (Demirkan \& Spohrer, 2014; Degeratu et al., 2000; Tsai \& Huang, 2007; Picot-Coupey et al., 2016).

\subsection{Mobile shopping}

Mobile commerce is increasing by 200\% more than online commerce (Ditrendia, 2016). In 2016, a 47\% of online shops that had mobile responsive webs say they have increased their sales from 10 to $25 \%$ thanks to mobile transactions (Ditrendia, 2016). The reasons mobile users state for using a smartphone to shop are: convenience, price, immediate purchase, and mainly because of advertising prompting (IAB, 2016). Mobile shopping experiences have very strong emotional significance for customers (Thakur, 2016) and is becoming a trend among millennials and a threat for physical stores. Although several forecasts show the enormous future potential of mobile shopping, there is insufficient adequate literature which attempts to investigate all relevant aspects of this shopping path (Groß, 2015). $78 \%$ of mobile shoppers use it to compare prices and $68 \%$ to search for opinions (Ditrendia, 2016). In this case, convenience and time saving are the main reasons why customers choose this way of shopping. According to different reports (Glass \& Haller, 2017; Ditrendia, 2016) mobile commerce is increasing drastically and will grow by almost 50\% in the next years. $33 \%$ of consumers who start mobile end mobile (Deloitte 2017) and that means that it is one of the most important shopping channels to be aware of. Mobile technologies are crucial due to the gap between offline and online channels (Mosquera et al., 2017) and therefore, a key purchase path for omnichannel retailing as it integrates and offers the seamless experience that the customer is looking for. 


\subsection{Showrooming}

As we have mentioned in previous chapters of this document, showrooming occurs when consumers use brickand-mortar stores to evaluate goods in person, and then go online to purchase for a better price. Whereas in the multichannel phase research shopping gained some attention (Gensler et al., 2017), in the omnichannel phase instant showrooming is becoming an important issue (Verhoef et al., 2015). Shoppers now frequently search for information in the store $(60 \%$ according to UPS, 2016) and simultaneously search on their mobile device to get more information about offers and may find more attractive prices (Rapp et al., 2015). In showrooming, consumers visit retailers' stores to "touch and feel" a product, but they consummate their eventual purchase online. In fact, about one-third of consumers say they have showroomed at some time (Fulgoni, 2014). The product and price transparency afforded by mobile technologies puts even more pricing pressures on physical retailers: either beat (or at least match) the online price or the shopper will walk out of the store empty-handed (Nelson \& Leon, 2012). When asked why they showroomed, 73 percent said it was because the price was lower online (Fulgoni, 2014) Consumer showrooming behaviour has been critiqued widely because showroomers often end up buying from a competitor's website (Zimmerman, 2012). Showrooming is dangerous for retailers as real purchases may end up in another channel and even to another retailer. Nevertheless, it may still be beneficial to the retailer if consumers facing stockouts can be persuaded to make the purchase on the retailer's own online channel (Gao \& Su, 2016). Showrooming works best for differentiated goods (Pricewaterhouse Coopers, 2017) and this allows retailers to create a competitive advantage over the competitors, either in the same shopping path or in a different one. Complementary services such as retailers' associates' help are important for the customer but price is still a very important factor. Searches and future purchases online are made based on price mainly. The threat to retail chains posed by showrooming and mobile commerce generally is overstated to the extent that in many cases the retailer will capture sales online that they previously might have transacted in a store (Nelson \& Leon, 2012).

\subsection{Webrooming}

Webrooming is the way in which consumers research products online before visiting a brick-and-mortar store for final evaluation and purchase (Edwards, 2014). Consumers mainly use it for convenience, especially if they need a product immediately. This should become more common as in-store inventory visibility increases on eCommerce sites. Also common for consumers who want to avoid shipping costs (Worldpay, 2015). Worldwide, $88 \%$ of consumers are seeking information online before buying in-store or in-app (Ingenico 2017). Webrooming is becoming more and more popular as shows that in Spain, 53\% of shoppers used the web to look for information prior to a purchase in 2015 and 65\% did so in 2016 (Ivend, 2017). In product categories where the touch-and-feel of the new product is crucial for consumers and the benefits of online shopping are relatively small (e.g., apparel and accessories), this positive surplus of switch consumers is an increasing function of product quality (Luo \& Sun, 2016). One of the main reasons why "webroomers" shop in stores is because of the immediate availability of the product, stock availability and personal interaction with shop associates. The same reasons as traditional shoppers, mainly. The need of touch and feel is important for most customers as well as immediate availability. Technology has changed the game when it comes to immediacy and reach of customer feedback, and it is also equipping retailers with better tools to listen and respond to those conversations (Rigby et al., 2014). Listening to customers should be a common practice among retailers. Even if customers research online prior to purchases, the need of "touch and feel" is more and more important. Thus, the atmosphere in the store plays an important role in the purchase process. Availability of stock and price are also key factors. Because the customer looks for information in the store and buys online, comparison tools and technology to experience how products would look in their homes is key for $41 \%$ of customers (Westfield, 2017).

\subsection{Instant showrooming}

When it comes to omnichannel paths, one of the main shopping practices is instant showrooming. The difference with showrooming is that the search is made in store and the purchase is also made there, at the same moment but through a different shopping channel. An important figure issued from our research is that $80 \%$ of 
smartphone shoppers use their mobile in store to help with shopping (Worldpay, 2015). Rather than simply providing web access in the store, retailers should optimize the interface for the in-store shopping environment (Burke, 2002). Customers while in store want to know if a wider rage is available online (Practicology, 2017) and also the price of a certain product. Customers acquired via showrooms (rather than stores) appear "conditioned" to accept online fulfilment and are therefore highly receptive to performing second and subsequent purchases directly online, at a cost greatly below that of serving repeat customers via stores (Bell et al., 2014).

The reason why customers follow an instant webrooming path is mainly because consumers find it important the ability to see or order an extended range of products on screen in-store. Availability of stock in the store is key to be able to offer the customer the sense of touch and feel they look for in a physical store (Neslin et al., 2006). Price is another reason why customers purchase online while in store. The fact that customers may buy not only from the same brand but also from other brands and stores is a key point for retailers. Consequently, retailers are starting to practice reverse showrooming, wherein they encourage bricks-and-mortar consumers to search their products online through kiosks or mobile apps, thereby increasing the likelihood of keeping the sale (Parise et al., 2016).

\subsection{BOPS}

The BOPS (Buy Online Pick up In Store) path combines both environments, online for purchases (see desktop consumers) and brick-and-mortar store. It is important to state that although $46 \%$ of BOPS customers have made additional purchases in store (UPS, 2016), still 39\% of brands do not offer a click and collect service. With this functionality, the retailer shows online viewers the locations at which the items are available and gives customers the option to close the transaction online and then pick up the products at one of the retailer's locations shortly after closing the purchase (Galino \& Moreno, 2014). Results from a study made by Galino and Moreno can be explained by two simultaneous phenomena: (1) additional store sales from customers who use the BOPS functionality and buy additional products in the stores (cross-selling effect) and (2) the shift of some customers from the online to the brick-and-mortar channel and the conversion of noncustomers into store customers (channel-shift effect) (Galino \& Moreno 2014). Convenience is the most valued factor among BOPS customers. They take the best of both worlds, online to search for information, and buy and the physical store to pick up and get the sense of touch and feel. The key point would be to attract more purchases from the customers who pick up in store and provide them with the convenience they expect not having to wait at queues.

Table 2 shows a summary of the different trigger factors according to the stages of the purchase process (information search, alternative evaluation and purchase) in every shopping path.

\begin{tabular}{|l|l|l|l|l|l|l|l|l|}
\hline TS & DO & MO & WR & IWR & SR & ISR & RS & BOPS \\
\hline $\begin{array}{l}\text { Personalisation } \\
\text { Stock } \\
\text { Convenience }\end{array}$ & $\begin{array}{l}\text { Price } \\
\text { Stock } \\
\text { Convenience }\end{array}$ & $\begin{array}{l}\text { Convenience } \\
\text { Price }\end{array}$ & $\begin{array}{l}\text { Stock } \\
\text { Price } \\
\text { Convenience }\end{array}$ & $\begin{array}{l}\text { Price } \\
\text { Stock }\end{array}$ & $\begin{array}{l}\text { Personalisation } \\
\text { Price } \\
\text { Stock }\end{array}$ & $\begin{array}{l}\text { Stock } \\
\text { Price }\end{array}$ & $\begin{array}{l}\text { Convenience } \\
\text { Stock }\end{array}$ & $\begin{array}{l}\text { Price } \\
\text { Stock } \\
\text { Convenience }\end{array}$ \\
\hline
\end{tabular}

TS= TraditionalShopping, $\mathrm{DO}=$ Desktop only, $\mathrm{MO}=$ Mobile only, WR=Webrooming, $\mathrm{SR}=$ Showrooming, IWR=Instant Webroomming, ISR = Instant Showrooming, RS= Reverseshowrooming

Table 2. Why do consumers use the different channels?

\section{Conclusions}

\subsection{Understanding purchase reasons}

Understanding customer purchase process and the reasons why they purchase again from the same brand is critical for firms. Customers now face multiple channels when looking for information, evaluating alternatives and purchasing. In an attempt to describe how important is every channel, we examine the different trigger factors of each channel and we have reached to the conclusion that the shopping experience is one only and that customers look forward to a seamless multichannel experience. Each channel has positive and negative aspects 
and retailers need to be aware of what is perceived by customers as key factors in every channel so as to rearrange the offer through the different channels. Customers look for the best of all offerings: stock availability, convenience, price, service quality, atmosphere, personalisation and complementary services and use different channels to make their purchases. If a customer can use different channels from the same brand to complete a purchase, then it is more likely that they complete the purchase within the same brand. It is at the retailer's hands to provide customers with an omnichannel experience so as to reach the desired engagement and loyalty, that is, repeat purchases and to lower attrition rates when moving from one channel to another one. Customers expect a seamless experience across the physical and digital worlds because they have the ability to use mobile technology to easily find the information needed to support their buying decisions wherever and whenever they choose (Fulgoni, 2014). Looking at results, we can observe that brand reputation is not considered as an important factor by customers. This can be due to the fact that when choosing a certain brand, customers expect other additional benefits rather than the brand itself or due to the fact that the choice of the brand is made before the information search stage.

\subsection{Foundation of the omnichannel concept}

While traditional multichannel \& E-Commerce literature contributed to the foundation of the omnichannel concept, additional literature in other areas provided useful knowledge regarding the simultaneous use of channels, which is the ultimate form of omnichannel and constitutes the prevalent behaviour of "omnishoppers" (consumers that use all channels simultaneously) (Lazaris et al., 2015). A truly omnichannel strategy means that firms must deliver consistent experiences, messages, content and processes to their customers across the available channels (Melero et al., 2016). Therefore, a conclusion that can arise from our research is that channels are more than channels and that they can be typologies of customers: the traditional customer, the "webroomer", the "showroomer", "the online shopper", the "m-shopper" among others. Knowing the purchase process of these typologies of customers will lead to a deep knowledge of how they behave and what are the key touchpoints with brands.

Despite the introduction of new channels by firms and the importance that customers attach to obtain a satisfactory and personalized experience through all the interactions in any of the available channels, most companies continue to manage their channels individually and separately (Melero et al., 2016). Brands are starting to offer their customers solutions that combine the best of both online and offline shopping (Glass \& Haller, 2017). Retailers are redefining the brand experience through new formats such as "click- and-collect," "delivery in 24 hours," "in-store ordering, home delivery," "order online, return to store," "click in store," and other combinations of online and traditional retail activities that facilitate and improve the shopping process and the customer experience (Bell et al., 2014). The consumer experience is determined by a mix of touchpoints to the brand, and how the retailer engages with each user in terms of providing immediate, personalized and emotional content will determine its success (Parise et al., 2016). The relationship between the brand and the customer goes beyond channels and in a seamless experience, channels interact and interfere one another. Omnichannel is moving towards a complete interaction of what could be defined as "interchannel", that is the total interaction of channels at every stage of the purchase process.

\subsection{Final conclusions: Implications of omnichannel shopping}

Omnichannel shopping has implications for all the actors in the purchase process. First the retailers because they need to avoid customers' attrition. Then the shop associates because they need to close deals after giving personal information and interacting with the customer. And finally, the customers themselves because they want the best of all worlds: the stock availability from online shops, the sense of touch and feel of physical stores and the convenience of BOPS. Giving customers what they want and guiding them through an omnichannel path should be the aim of retailers: allow the shift from one channel to another without losing the customer is key for acquiring new loyal customers. According to research made by Aberdeen Group companies that use an omnichannel strategy retain $89 \%$ of their clients and companies that don't use it retain only a $33 \%$. As we have mentioned before, a process of reverse showrooming would help retailers keep customers loyal and therefore, help them to repurchase products or services from the same brand. In none of the reports we have studied is 
brand reputation a variable that customers take into consideration when repeating purchases. This must lead companies to rethink their communication strategies and give more importance to what is really valued so that we can define a correct omnichannel strategy. Traditional shopping is not dying as some may think. It is only being transformed and fed with technological innovations that help customers make decisions. Immediacy and the need to touch and feel are vital for consumers. It is true that they come to the store much better informed but also with a higher disposition to purchase (Parise et al., 2016). They want to be treated personally and need to find a sales associate that answers precise questions (Worldpay, 2015). Training the sales force is key for retail stores as well as adapting to the last technology so that customers can complete their purchases on site and therefore, retain them. Knowing the factors that customers value in different channels will help companies increase the client's life-time value and reinforce the customers' interactions with the brand so as to build a brand engagement.

\section{Declaration of Conflicting Interests}

The authors declared no potential conflicts of interest with respect to the research, authorship, and/or publication of this article.

\section{Funding}

The authors received no financial support for the research, authorship, and/or publication of this article.

\section{References}

Accenture (2017). See Beyond the Customer Loyalty Illusion. Retrieved from: https://www.accenture.com/t20170216T002701Z w /us-en/ acnmedia/PDF-43/Accenture-Strategy-GCPRCustomer-Loyalty Infographic.pdf\#zoom $=50$ (Last access date: July 28th, 2017)

Agnihotri, A. (2015). Can Brick-and-Mortar Retailers Successfully Become Multichannel Retailers?. Journal of Marketing Channels, 22(1), 62-73. Retrieved from: http://www.tandfonline.com/doi/abs/10.1080/1046669X.2015.978702 https://doi.org/10.1080/1046669X.2015.978702

Ajzen, I. (2011). The theory of planned behaviour: Reactions and reflections. Psychology \& Health, 26(9), 1113-1127. https://doi.org/10.1080/08870446.2011.613995

Andajani, E. (2015). Understanding Customer Experience Management in Retailing. Procedia - Social and Behavioral Sciences, 211(September), 629-633. Retrieved from: http://linkinghub.elsevier.com/retrieve/pii/S1877042815054221 https://doi.org/10.1016/j.sbspro.2015.11.082

Beck, N., \& Rygl, D. (2015). Categorization of multiple channel retailing in Multi-, Cross-, and Omni-Channel Retailing for retailers and retailing. Journal of Retailing and Consumer Services, 27, 170-178. https://doi.org/10.1016/j.jretconser.2015.08.001

Bell, D.R., Gallino, S., \& Moreno, A. (2014). How to Win in an Omnichannel World. MIT Sloan Management Review, 56(1), 45-54.

Brynjolfsson, E., Hu, Y.J., \& Rahman, M.S. (2013). Competing in the Age of Omnichannel Retailing. MIT Sloan Management Review, 54(4), 23-29. Retrieved from: http://sloanreview.mit.edu/article/competing-in-the-age-ofomnichannel-retailing/

Burke, R.R. (2002). Technology and the Customer Interface: What Consumers Want in the Physical and Virtual Store. Journal of the Academy of Marketing Science, 30(4), 411-432. Retrieved from: http://link.springer.com/10.1177/009207002236914 https://doi.org/10.1177/009207002236914

Cap Gemini (2017). Making the Digital Connection: Why Physical Retail Stores Need a Reboot. Retrieved from: https://www.capgemini-consulting.com/sites/default/files/resource/pdf/retail-store-research dti.pdf

Dailey, L. (2004). Navigational web atmospherics: Explaining the influence of restrictive navigation cues. Journal of Business Research, 57(7), 795-803. https://doi.org/10.1016/S0148-2963(02)00364-8 
Degeratu, A.M., Rangaswamy, A., \& Wu, J. (2000). Consumer choice behavior in online and traditional supermarkets: The effects of brand name, price, and other search attributes. International Journal of Research in Marketing, 17(1), 55-78. https://doi.org/10.1016/S0167-8116(00)00005-7

Deloitte (2017). Think big, start small, connect now. Omnichannel fulfilment in 2017. Retrieved from: https://www2.deloitte.com/nl/nl/pages/consumer-industrial-products/articles/omnichannel.html

Demirkan, H., \& Spohrer, J. (2014). Developing a framework to improve virtual shopping in digital malls with intelligent self-service systems. Journal of Retailing and Consumer Services, 21(5), 860-868.

https://doi.org/10.1016/j.jretconser.2014.02.012

Ditrendia (2016). Informe ditrendia Mobile en España y en el Mundo 2016. Retrieved from: http://www.ditrendia.es/informe-ditrendia-mobile-en-espana-y-en-el-mundo-2016/

Edwards, G. (2014). The Retail TouchPoints Blog How To Embrace Retail's Newest Trend: Webrooming. https://Retailtouchpoints. Tumblr.Com/Post (pp. 1-6). Retrieved from: http://retailtouchpoints.tumblr.com/post/59107311088/how-to-embrace-retails-newest-trend-webrooming

Evanschitzky, H. et al. (2004). E-satisfaction: A re-examination. Journal of Retailing, 80(3), 239-247. https://doi.org/10.1016/j.jretai.2004.08.002

Frank, B., Enkawa, T., \& Schvaneveldt, S.J. (2014). How do the success factors driving repurchase intent differ between male and female customers?. Journal of the Academy of Marketing Science, 42(2), 171-185. https://doi.org/10.1007/s11747-013-0344-7

Fulgoni, G.M. (2014). Numbers, Please “ Omni-Channel ” Retail Insights and The Consumer' s Path-toPurchase How Digital Has Transformed. Journal of Advertising Research, 54(December), 1-4. https://doi.org/10.2501/JAR-54-4-377-380

Galino, S., \& Moreno, A. (2014). Integration of online and offline channels in retail: The impact of sharing reliable inventory availability information. Management Science, 60(6), 1434-1451. Retrieved from: http://www.scopus.com/inward/record.url?eid=2-s2.084902251292\&partnerID=40\&md5=0c4bf39f5022186e0fd1dd470e63fa6b

Gao, F., \& Su, X. (2016). Online and Offline Information for Omnichannel Retailing. Manufacturing \& Service Operations Management, November, 16. Retrieved from: http://pubsonline.informs.org/doi/10.1287/msom.2016.0593 https://doi.org/10.2139/ssrn.2796566

Gao, R., \& Yang, Y. (2016). Consumers 'Decision: Fashion Omni-channel Retailing. Journal of Information Hiding and Multimedia Signal Processing, 7(2), 325-342.

Gensler, S., Neslin, S.A., \& Verhoef, P.C. (2017). The Showrooming Phenomenon: It's More than Just About Price. Journal of Interactive Marketing, 38, 29-43. https://doi.org/10.1016/j.intmar.2017.01.003

Glass, S., \& Haller, K.H. (2017). The 2017 Customer Experience Index (CEI) Study. Retrieved from: https://www.royalcyber.com/wp-content/uploads/2017/01/CEI.pdf

Groß, M. (2015). Mobile shopping: A classification framework and literature review. International Journal of Retail \& Distribution Management, 43(3), 221-241. https://doi.org/10.1108/IJRDM-06-2013-0119

Hagberg, J., Sundstrom, M., \& Egels-Zandén, N. (2016). The digitalization of retailing: An exploratory framework. International Journal of Retail \& Distribution Management, 44(7), 694-712. Retrieved from: http://www.emeraldinsight.com/doi/10.1108/IJRDM-09-2015-0140 https://doi.org/10.1108/IJRDM-09-2015-0140

Heitz-Spahn, S. (2013). Cross-channel free-riding consumer behavior in a multichannel environment: An investigation of shopping motives, sociodemographics and product categories. Journal of Retailing and Consumer Services, 20(6), 570-578. https://doi.org/10.1016/j.jretconser.2013.07.006

Howard, J.J., \& Shethe, J.N. (1969). The theory of buyer behavior. New York: Wiley.

HP (2014). HP's Journey to Customer. Retrieved from: http://h20195.www2.hp.com/v2/getpdf.aspx/4AA50517EEE.pdf 
IAB (2016). A Global Perspective of Mobile Commerce. Retrieved from: https://www.iab.com/wpcontent/uploads/2016/09/2016-IAB-Global-Mobile-Commerce-Report-FINAL-092216.pdf

Ingenico (2017). The Demand for Cross-Channel Payment Infrastructure Service. Retrieved from: https://www.ingenico.com/press-and-publications/library/white-papers/omnichannel-retailing.html

Ivend (2017). The omni progress. Retrieved from: https://ivend.com/download-omnichannel-research-report-2017-eu/

Juaneda-Ayensa, E., Mosquera, A., \& Sierra, Y. (2016). Omnichannel Customer Behavior: Key Drivers of Technology Acceptance and Use and Their Effects on Purchase Intention. Frontiers in Psychology Front. Psychol, 7(7), 1-11. https://doi.org/10.3389/fpsyg.2016.01117

Karimi, S., Papamichail, K.N., \& Holland, C.P. (2015). The effect of prior knowledge and decision-making style on the online purchase decision-making process: A typology of consumer shopping behaviour. Elsevier B.V., 77, 137-147. https://doi.org/10.1016/j.dss.2015.06.004

Khan, S.A. et al. (2015). Impact of word of mouth on consumer purchase intention. Sci.Int.(Lahore), 27(1), 479-482.

Kibo (2017). The ultimate guide to personalization. Retrieved from: https://kibocommerce.com/wpcontent/uploads/Kibo-The-Ultimate-Guide-to-Personalization.pdf

Kim, D.J., Ferrin, D.L., \& Rao, H.R. (2008). A trust-based consumer decision-making model in electronic commerce: The role of trust, perceived risk, and their antecedents. Decision Support Systems, 44(2), 544-564. https://doi.org/10.1016/j.dss.2007.07.001

Kim, J., \& Forsythe, S. (2007). Hedonic usage of product virtualization technologies in online apparel shopping. International Journal of Retail \& Distribution Management, 35(6), 502-514. https://doi.org/10.1108/09590550710750368

Kollat, D.T., Engel, J.F., \& Blackwell, R.D. (1970). Current Problems in Consumer Behavior Research. Journal of Marketing Research, 7(3),.327-332. Retrieved from: http://www.jstor.org/stable/3150290 https://doi.org/10.1177/002224377000700307

Kotler, P., \& Keller, K.L. (2009). Marketing Management. Retrieved from: http://search.ebscohost.com/login.aspx? direct $=$ true\&db=bth\&AN $=44033223 \&$ site $=$ ehost-live

Lazaris, C. et al. (2015). The Interplay of Omniretailing Store Atmosphere on Consumers Purchase Intention towards the Physical Retail Store. In European, Mediterranean Middle Eastern Conference on Information Systems (1-16). Retrieved from:

http://www.researchgate.net/publication/280580317 The Interplay of Omniretailing Store Atmosphere on Consu mers Purchase Intention towards the Physical Retail Store

Lazaris, C., \& Vrechopoulos, A. (2013). From Multichannel to "Omnichannel" Retailing: Review of the Literature and Calls for Research. 2nd International Conference on Contemporary Marketing Issues, (ICCMI)., JUNE 2014, 6 .

Lemon, K.N., \& Verhoef, P.C. (2016). Understanding Customer Experience and the Customer Journey. Journal of Marketing, 80(JM-MSI Special Issue), 1-62. https://doi.org/10.1509/jm.15.0420

Levy, M., \& Weitz, B. (2013). Retailing Management (9th edition). New York: McGraw-Hill.

Li, Z. (Erick), Lu, Q., \& Talebian, M. (2014). Online versus bricks-and-mortar retailing: a comparison of price, assortment and delivery time. International Journal of Production Research, 53(13), 1-14.

https://doi.org/10.1080/00207543.2014.973074

Luo, L., \& Sun, J. (2016). New Product Design under Channel Acceptance: Brick-and-Mortar, Online-Exclusive, or Brick-and-Click. Production and Operations Management, 25(12), 2014-2034. https://doi.org/10.1111/poms.12587

Martos-Partal, M., \& González-Benito, Ó. (2013). Studying motivations of store-loyal buyers across alternative measures of behavioural loyalty. European Management Journal, 31(4), 348-358.

https://doi.org/10.1016/j.emj.2013.01.010 
Melero, I., Sese, F.J., \& Verhoef, P. (2016). Recasting the Customer Experience in Today's Omni-channel Environment. Universia Business Review, (Second Quarter), 1-20.

Mosquera, A., Olarte Pascual, C., \& Juaneda Ayensa, E. (2017). Understanding the customer experience in the age of omni-channel shopping. Revista ICONO14 Revista cientifica de Comunicación y Tecnologías emergentes, 15(2), 92. Retrieved from: http://www.icono14.net/ois/index.php/icono14/article/view/1070 https://doi.org/10.7195/ri14.v15i2.1070

Nelson, A., \& Leon, A. (2012). Bricks and Clicks: Retbinking Retail Real Estate in the E-commerce Era. Retrieved from: http://scholar.google.com/scholar?hl=en\&btnG=Search\&q=intitle:Bricks+and+Clicks+: + Rethinking + Retail + Real + Estate + in + the + E-commerce + Era\#0

Neslin, S.A. et al. (2006). Challenges and Opportunities in Multichannel Customer Management. Journal of Service Research, 9(2), 95-112. Retrieved from: http://journals.sagepub.com/doi/10.1177/1094670506293559 https://doi.org/10.1177/1094670506293559

Parise, S., Guinan, P.J., \& Kafka, R. (2016). Solving the crisis of immediacy: How digital technology can transform the customer experience. Business Horizons, 59(4), 411-420. https://doi.org/10.1016/j.bushor.2016.03.004

Pawar, S., \& Sarmah, T. (2015). Omni-Channel Retailing: the Opulent Blend Moving Towards a Customer. Journal of Arts, Science \& Commerce, VI(July), 0-10.

Picot-Coupey, K., Huré, E., \& Piveteau, L. (2016). Channel design to enrich customers' shopping experiences Synchronizing clicks with bricks in an omni-channel perspective - the Direct Optic case. International Journal of Retail \& Distribution Management, 44(3), 336-368. https://doi.org/10.1108/IJRDM-04-2015-0056

Piotrowicz, W., \& Cuthbertson, R. (2014). Introduction to the Special Issue Information Technology in Retail: Toward Omnichannel Retailing. International Journal of Electronic Commerce, 18(4), 5-16. Retrieved from: http://www.tandfonline.com/doi/full/10.2753/JEC1086-4415180400 https://doi.org/10.2753/JEC1086-4415180400

Practicology (2017). Ranking 30 UK retailers on the omnichannel experience they provide to customers. Retrieved from: https://www.practicology.com/download_file/force/452/1879

Pricewaterhouse Coopers (2017). Industry Trends consumer experience, and compelling economics Minneapolis. Retrieved from: https://www.strategyand.pwc.com/media/file/2017-Retail-Industry-Trends.pdf

PSFK Labs; Cisco (2016). Future of retail. Retrieved from: http://www.psfk.com/download file/176152279/wc order 579690215b312/gtaheriz \%40ryerson.ca/3687f2d45b28d74f90d7e8caeb09bd44/FoR TechnologyPrimer Digital.pdf

PWC (2017). Total Retail 2017. Retrieved from: http://www.pwc.com/gx/en/industries/assets/total-retail-2017.pdf

Rajamma, R.K., Paswan, A.K., \& Ganesh, G. (2007). Services purchased at brick and mortar versus online stores, and shopping motivation. Journal of Services Marketing, 21(3), 200-212. https://doi.org/10.1108/08876040710746552

Rapp, A. et al. (2015). Perceived customer showrooming behavior and the effect on retail salesperson selfefficacy and performance. Journal of Retailing, 91(2), 358-369. https://doi.org/10.1016/j.jretai.2014.12.007

Rigby, D. et al. (2014). Spotlight on Technology. Bain Retail Holiday Newsletter, 2, 1-3. Retrieved from: https://www.bain.com/insights/retail-holiday-newsletter-2014-2015-issue-2/

Rigby, D. (2011). The Future of Shopping. Harvard Business Review, 65-76. Retrieved from: https://hbr.org/2011/12/the-future-of-shopping (Last access date: July 17th, 2017)

Ryu, K., \& Han, H. (2011). The influence of physical environments on disconfirmation, customer satisfaction, and customer loyalty for first-time and repeat customers in upscale restaurants. In International Journal of Hospitality Management, 599-611. https://doi.org/10.1016/j.ijhm.2010.11.004

Sands, S. et al. (2016). Segmenting multichannel consumers across search, purchase and after-sales. Journal of Retailing and Consumer Services, 33, 62-71. https://doi.org/10.1016/j.jretconser.2016.08.001 
Schiffman, L.G., \& Wisenblit, J. (1995). Consumer behaviour. European Journal of Marketing, 29(5), 44. Retrieved from: http://search.ebscohost.com/login.aspx?direct=true\&db=bth\&AN=9508210049\&lang=it\&site=ehost-live

Schröder, H., \& Zaharia, S. (2008). Linking multi-channel customer behavior with shopping motives: An empirical investigation of a German retailer. Journal of Retailing and Consumer Services, 15(6), 452-468. https://doi.org/10.1016/j.jretconser.2008.01.001

Thakur, R. (2016). Understanding Customer Engagement and Loyalty: A Case of Mobile Devices for Shopping. Journal of Retailing and consumer Services, 32(1), 151-163. https://doi.org/10.1016/j.jretconser.2016.06.004

Tsai, H.T., \& Huang, H.C. (2007). Determinants of e-repurchase intentions: An integrative model of quadruple retention drivers. Information and Management, 44(3), 231-239. https://doi.org/10.1016/j.im.2006.11.006

UPS (2015). 2015 UPS Pulse of the Online Shopper TM. Retrieved from: https://www.pressroom.ups.com/assets/pdf/pressroom/fact \%20sheet/2015 Domestic Pulse of the Online Shopper Executive Summary.pdf

UPS (2016). Tech-savvy shoppers transforming retail Shiny new objects Channel dynamics The ready retailer. Retrieved from: https://www.ups.com/assets/resources/media/knowledge-center/2016 UPS Pulse of the Online Shopper

Verhoef, P.C., Kannan, P.K., \& Inman, J.J. (2015). From Multi-Channel Retailing to Omni-Channel Retailing. Introduction to the Special Issue on Multi-Channel Retailing. Journal of Retailing, 91(2), 174-181. https://doi.org/10.1016/j.jretai.2015.02.005

Westfield (2015). How We Shop Now. Retrieved from: http://uk.fashionnetwork.com/news/Westfield-reveals-How-WeShop-Now-,626167.html\#.WYibMIjvg2w (Last access date: August 7th, 2017)

Westfield (2017). How We Shop Now What'S Next?. Retrieved from: https://uk.westfield.com/how-we-shop-now

Willmott, B. (2014). Retail showrooms, mobile sales. Journal of Direct, Data and Digital Marketing Practice, 15(3), 229-232. Retrieved from: http://link.springer.com/10.1057/dddmp.2014.4 https://doi.org/10.1057/dddmp.2014.4

Wolny, J., \& Charoensuksai, N. (2014). Mapping customer journeys in multichannel decision-making. Journal of Direct, Data and Digital Marketing Practice, 15(4), 317-326. Retrieved from: http://www.palgravejournals.com/doifinder/10.1057/dddmp.2014.24 https://doi.org/10.1057/dddmp.2014.24

Worldpay (2015). The Store of the Future and the Role of Omni-Channel Payments in Driving Business Growth. Retrieved from: https://www.worldpay.com/sites/default/files/WPUK-Omni-channel-payments-store-of-the-future.pdf

Zeithaml, A., Berry, L., \& Parasuraman, A. (1996). Behavioral Consequences of Service Quality. Journal of Marketing, 60(2), 31-46. https://doi.org/10.2307/1251929

Zimmerman, A. (2012). Can Retailers Halt "Showrooming"?. Retrieved from: https://www.wsi.com/articles/SB10001424052702304587704577334370670243032

Article's contents are provided on an Attribution-Non Commercial 4.0 Creative commons International License. Readers are allowed to copy, distribute and communicate article's contents, provided the author's and Intangible Capital's names are included. It must not be used for commercial purposes. To see the complete license contents, please visit https://creativecommons.org/licenses/by-nc/4.0/. 